\title{
PENGEMBANGAN MEDIA PEMBELAJARAN RODA PUTAR FISIKA UNTUK MENINGKATKAN MOTIVASI BELAJAR SISWA
}

\author{
Hamzah $^{11}$, Linda Sekar Utami1 ${ }^{1}$, Zulkarnain ${ }^{1)}$ \\ 1)Program Studi Pendidikan Fisika, Universitas Muhammadiyah Mataram \\ Corresponding author: Hamzah \\ E-mail: hamzahpfis@gmail.com
}

Diterima 01 November 2019, Disetujui 23 November 2019

\begin{abstract}
ABSTRAK
Penelitian ini bertujuan untuk mengembangkan media pembelajaran pada mata pelajaran ilmu pengetahuan alam (IPA) Fisika pada kelas VIII.C di MTs Al-Raisiyah Mataram, menggunakan media pembelajaran berbasis roda putar fisika untuk meningkatkan motivasi belajar siswa. Penelitian ini merupakan Penelitian research and developmen. Media pembelajaran roda putar IPA Fisika ini berbentuk game alat peraga untuk memotivasi belajar siswa pada materi pesawat sederhana. Media ini divalidasi oleh 4 ahli, 1 ahli media dan 3 ahli fisika yang menunjukan bahwa hasil untuk kriteria pendidikan 4 ahli memberikan nilai $A$, untuk kriteria tampilan 2 ahli memberikan nilai $A$ satu ahli memberikan nilai $B$ dan $C$ dan kriteria teknis 4 ahli memberikan niali A. Media roda putar fisika yang dikembangkan juga memiliki kriteria yang sangat baik untuk meningkatkan motivasi belajar siswa dengan persentase sebesar $75 \%$ bila dibandingkan sebelum menggunakan roda putar fisika yaitu sebesar $56,25 \%$. Peningkatan motivasi belajar secara klasikal juga berada pada kriteria sedang dengan normalisasi gain sebesar 0,42. Berdasarkan hasil dari penelitian ini dapat disimpulkan bahwa media pembelajaran roda putar fisika dapat meningkatkan motivasi belajar siswa kelas VIII.C di MTs Al-Raisiyah Mataram 2016-2017.
\end{abstract}

Kata kunci : Pengembangan Media pembelajaran; Roda Putar Fisika; Motivasi Belajar.

\begin{abstract}
This study aims to develop learning media on Physics (IPA) Physics subjects in class VIII.C at MTs AlRaisiyah Mataram, using a learning wheel based on physics spinning wheels to increase student motivation. This research is a research and development research. The physics science learning wheel media in the form of game props to motivate student learning on simple aircraft material. This media was validated by 4 experts, 1 media expert and 3 physicists who showed that the results for the educational criteria 4 experts gave a value of $A$, for display criteria 2 experts gave an $A$ value one expert gave a value of $B$ and $C$ and technical criteria 4 experts gave a value of $A$ The physics spinning wheel media developed also has very good criteria to increase student motivation by a percentage of $75 \%$ compared to before using the physics spinning wheel that is equal to $56,25 \%$. Increased motivation to learn classically is also in the medium criteria with a normalization gain of 0,42 . Based on the results of this study it can be concluded that the learning media of the physics turning wheel can increase the motivation of students in class VIII.C at MTs AI-Raisiyah Mataram 2016-2017.
\end{abstract}

Keywords : Learning Media Development; Physics Turn Wheel; Learning Motivation.

\section{PENDAHULUAN}

Dunia pendidikan adalah dunia yang sangat penting dalam kehidupan manusia. Manusia yang berpendidikan kehidupannya akan selalu berkembangkearah yang lebih baik. Setiap zaman, pasti akan selalu ada perubahan yang mengarah pada kemajuan pendidikan. Disamping itu, dunia pendidikan juga memerlukan berbagai inovasi (pembaharuan). Hal ini penting dilakukan untuk kemajuan kualitas pendidikan yang tidak hanya menekankan pada teori, tetapi juga harus bisa diarahkan pada hal yang bersifat praktis. Maka dari itu, dibutuhkan inovasi pembelajaran agar para siswabersemangat, mempunyai motivasi untuk belajar dan antusias menyambut pelajaran disekolah.

Permendiknas RINo. $41 \quad$ (2007) dalamMardapi (2007:06 ) menyatakan bahwa proses pembelajaran pada setiap satuan pendidikan dasar dan menengah harus interaktif, inspiratif, menyenangkan, menantang, dan memotivasi peserta didik untuk berpartisipasi aktif serta memberikan ruang yang cukup bagi pesertadidik, kreativitas dan kemandirian sesuai dengan bakat, minat, 
dan perkembangan fisik serta psikologis peserta didik. Disetiap satuan pendidikan guru tidak hanya berperan kreatif dalam memberikan inovasi dalam proses pembelajaran, tetapi guru juga harus bisa membuat siswa menjadi pandai sekaligus kreatif. Guru dan siswa yang kreatif khususnya dalam penerapan pembelajaran IImu Pengetahuan Alam (IPA) Terpadu akan menghasilkan pembelajaran yang sangat menarik karena IPA terpadu mudah ditemukan dalam kehidupan sehari-hari.

Berdasarkan hasil observasipeneliti dilakukan di MTs Al-RaisiyahMataram, diperoleh informasi bahwa terdapat kendala dalam proses belajar mengajar di kelas.Pembelajaranmasih berpusat pada guru (teacher centered) atau yang sering disebut dengan pembelajaran behaviorisme. Pembelajaran behavioris dimana guru lebih banyak mengajarkan tentang konsep-konsep bukan kompetensi, tujuannya adalah siswa mengetahui sesuatu, bukan mampu untuk melakukan sesuatu, dan pada saat proses pembelajaran siswa lebih banyak mendengarkan.

Permasalahan tersebut harusnya segera diatasi dan diperlukan suatu cara untuk menerapkan strategi pembelajaran yang efektif, yaitu suatu strategi yang tidak mengharuskan siswa menghafal tetapi mendorong siswa untuk mengetahui lebih luasilmu pengetahuan dibenak mereka sendiri. Disamping pemilihan strategis pembelajaran perlu dilakukan suatu pengembangan media pembelajaran yang sesuai dengan materi untuk meningkatkanmotivasi belajar siswa. Salah satu media pembelajaran yang dikembangkan oleh peniliti adalah media pembelajaran roda putar fisika berbentuk game untuk memotivasi belajar siswa.

Mediapembelajaran roda putar adalah salah satu alat yang berbentuk lingkaran bergambar yang diputar, bergerak pada porosnya hingga berhenti disalah satu bagian gambar (Noni, 2016). Desainisi pada media tersebut adalah tentang konsep materi pesawat sederhana.Menurut Sadiman dalam Arsyad (2015:10) sebagai media pembelajaran game mempunyai beberapa kelebihan yaitu: (1) permainan adalah sesuatu yang menyenangkan untuk dilakukan sesuatu yang menghibur dan menarik (2) permainan memungkinkan akan adanya partisipasi aktif dari siswa untuk belajar (3) permainan dapat memberikan umpan balik secara langsung dengan memecahkan masalah-masalah yang nyata (4) permainan memberikan pengalamanpengalaman yang nyatadan dapat diulangi sebanyak yang dikehendaki, kesalahan- kesalahan operasional dapat diperbaiki (5) membantu siswa meningkatkan kemampuan komunikatif.

\section{METODE PENELITIAN}

Penelitian inidilaksanakan pada bulan Juli-Agustus semester genap Tahun Pelajaran 2017/2018.Penelitian inidilaksanakan padasiswa kelas VIII.C di MTs Al-Raisiyah Mataram Tahun Pelajaran 2017/2018.Desain produk dalam penelitian ini diwujudkan dalam bentuk game dengan bentuk media roda yang berputar.Metode penelitian digunakan metode penelitian dan pengembangan (research and development) untuk menghasilkan produk tertentu dan menguji keefektifan produk tersebut (Sugiyono, 2010: 407).

Teknik analisis data pada penelitian ini bertujuan untuk mendapatkan perangkat pembelajaran yang berkualitas. Adapunlangkah-langkah yang digunakan dalam memenuhi kriteria kualitas produk yang dikembangkan adalah sebagai berikut:

a. Data berupa skor ahli/praktisi yang diperoleh melalui lembar validasi yang dijumlahkan.

b. Total skor aktual yang diperoleh kemudian dikonversikan menjadi data kualitatif skala lima seperti pada tabel berikut:

Tabel 1. Konversi data kuantitatif ke kualitatif dengan skala lima

\begin{tabular}{|c|c|c|}
\hline Interval & Kriteria & Skor \\
\hline$(M+1,50 s)<X$ & Sangat baik & $\mathrm{A}$ \\
\hline$(M+0,50 s)<X \leq(M+1,50 s)$ & Baik & $\mathrm{B}$ \\
\hline$(M-0,50 s)<X \leq(M+0,50 s)$ & Cukup baik & $\mathrm{C}$ \\
\hline$(M-1,50 s)<X \leq(M-0,50 s)$ & Kurang baik & $\mathrm{D}$ \\
\hline$X \leq(M-1,50 s)$ & Tidak baik & $\mathrm{E}$ \\
\hline
\end{tabular}

(Azwar, 2015:163)

Dengan $\dot{X}$ rerata skor ideal $=1 / 2$ (skor maksimal ideal + skor minimal ideal) , $S b_{i}$ simpangan baku ideal $=1 / 6$ (skor maksimal ideal-skor minimal ideal), Xtotal skor aktual, Skor maksimal ideal $=\Sigma$ butir kriteria $\times$ skor tertinggi dan Skor minimal ideal $=\Sigma$ butir kriteria $\times$ skor terendah.

Berdasarkan kriteria yang terdapat pada tabel 1 kemudian dibuat kriteria validitas perangkat pembelajaran yang dikembangkan. Komponen perangkat pembelajaran yang dikembangkan memiliki jumlah butir pada lembar validasi untuk angket penilaian berbeda-beda, maka kriteria kevalidannya juga berbeda. Hasil validasi oleh ahli kemudian dikonversikan menjadi skala lima. Perangkat pembelajaran yang dikembangkan dikatakan valid, jika minimal tingkat validitas.

Analisa data dilakukan setelah proses pengumpulan data. Penelitian ini lebih menitik beratkan pada pengembangan media 
pembelajaran roda putar fisika pada materi pesawat sederhana. Selain itu, angket yang digunakan harus dilakukan uji validitas dan uji reliabilitas.

\section{Uji validitas}

Dengan persamaan korelasi product moment, dapat dihitung nilai validitas pernyataanyaitu:

$$
\begin{gathered}
r_{x y}=\frac{N \sum X Y-\left(\sum X\right)\left(\sum Y\right)}{\sqrt{\left\{N \sum X^{2}-\left(\sum X\right)^{2}\right\}\left\{N \sum Y^{2}-\left(\sum Y\right)^{2}\right\}}}(1) \\
\text { dengan } r_{x y} \text { koefisien korelasi product }
\end{gathered}
$$

momen, $\sum X$ jumlah skor butir soal $\sum Y$ jumlah skor total, Njumlah responden, $\sum X^{2}$ jumlah kuadrat skor butir soal $\sum Y^{2}$ jumlah kuadrat skor total soal dan $\sum X Y$ jumlah hasil kali skor butir soal

Uji signifikasi korelasi product moment dikonsultasikan pada $r$ tabel productmoment dengan taraf kesalahan $5 \%$. Apabila $r$ hitung lebih besar dari $r$ tabel maka soalnya valid, tetapi jika $r$ hitungnya lebih kecil dari $r$ tabel maka soalnya tidak valid (AnasSudijono 2007:181).

\section{Uji reliabilitas}

Uji reliabilitas dilakukan untuk mengetahui reliabilitas angket, (instrument) yang digunakan. Langkahlangkah mencari nilai reliabilitas sebagai berikut:

$$
r_{11}=\left(\frac{n}{n-1}\right)\left(1-\frac{\sum S_{i}^{2}}{S^{2}{ }_{t}}\right)
$$

dengan $r_{11}$ koefisiennilai reliabilitas $\sum S_{i}{ }^{2}$

Jumlah varians skor tiap-tiap item, $S^{2}{ }_{t}$ varians total, nbanyaknyaJumlahbutir item yang dikeluarkandalamtes dan 1 bilangan konstan.

Selain itu perlu dicari nilai varians untuk menentukan reliabilitas angketmotivasi belajar siswa menggunakan rumus sebagai berikut:

$$
S_{i}=\frac{\sum X_{i}^{2}-\frac{\left(\sum X_{i}\right)^{2}}{N}}{N}
$$

dengan $S_{i}$ varians skor tiap-tiap item, $\sum X_{i}^{2}$ jumlah kuadrat item $X_{i},\left(\sum X_{i}\right)^{2}$ jumlah item, $X_{i}$ dikuadratkanNjumlah responden

Nilai korelasi yang diperoleh dikonsultasikan ke tabel Product Moment dengan taraf $\propto=0,05$ atau $\propto=$ 0,01 . Jika harga $r_{\text {hitung }}>r_{\text {tabel }}$ maka reliabel dan harga $r_{\text {hitung }}<r_{\text {tabel }}$ berarti tidak reliabel (AnasSudijono, 2007:208).

3. Motivasi belajar siswa

Untuk menghitung angket tingkat motivasi siswa digunakan persamaan berikut:

Tabel 2. Penilaian skala 1-5 motivasi belajar siswa

\begin{tabular}{|c|c|c|}
\hline Interval & Konnersi nilai & Skor \\
\hline$(M+1,50 s)<X$ & $76 \%-100 \%$ & A \\
\hline$(M+0,50 s)<X \leq(M+1,50 s)$ & $59 \%-75 \%$ & B \\
\hline$(M-0,50 s)<X \leq(M+0,50 s)$ & $43 \%-58 \%$ & C \\
\hline$(M-1,50 s)<X \leq(M-0,50 s)$ & $25 \%-42 \%$ & D \\
\hline$X \leq(M-1,50 s)$ & $0 \%-25 \%$ & E \\
\hline
\end{tabular}

Dengan $X$ total skor responden, Mmean ideal, $1 / 2$ (skor maksimal ideal+skor minimal ideal) dan ssimpangan baku ideal, 1/6 (skor maksimal ideal-skor minimal ideal)

Data motivasi belajar siswa diolah tiap pernyaan kemudian diolah berdasarkan indikator. Data perindikator setelah diolah maka motivasi belajar siswa dapat diketahui. Data motivasi belajar siswa dihitung dengan persamaan berikut:

$$
\%=\left(\frac{n}{N}\right) x 100 \%
$$

dengan $n$ skor yang diperoleh dan $N$ jumlah seluruh skor maksimal

Menghitungbesarnya peningkatan hasil belajar siswa dengan menggunakan rumus Hake:

$$
g=\frac{S_{\text {post }}-S_{\text {pre }}}{100-S_{\text {pre }}}
$$

dengan ggain, $S_{\text {preskor awal dan }}$ Spost $_{\text {skor }}$ akhir.

Data hasil perhitungan angket motivasi sebelum dan sesudah siswa kemudian akan diinterpretasikan dengan menggunakan gain standar sebagai berikut:

Tabel 3. Nilai indeks gain standar

\begin{tabular}{|l|c|}
\hline \multicolumn{1}{|c|}{ Nilai gain standar } & Keterangan \\
\hline $0,7<\mathrm{g}<1$ & Tinggi \\
\hline $0,3 \leq, \mathrm{g} \leq 0,7$ & Sedang \\
\hline $0<\mathrm{g}<0,3$ & Rendah \\
\hline
\end{tabular}

Apabila media pembelajaran dapat meningkatkan motivasi belajar siswa, maka media pembelajaran dikatakan telah teruji keefektifannya. 


\section{HASIL DANPEMBAHASAN}

\section{Desain produk}

Roda putar fisika yang dibuat memiliki jenis dan ukuran tulisan yang mudah dibaca serta konsistensi penomoran pada media dan kartu soalnya. Desain awal produk dikerjakan dengan menggunakan beberapa alat dan bahanya serta program microsoft office publizer2007 untuk mendesain kartu soal kemudian dicetak dengan menggunakan kertas A4 kuarto, Penggaris, Alat pemotong kayu cat kayu dan triplek.

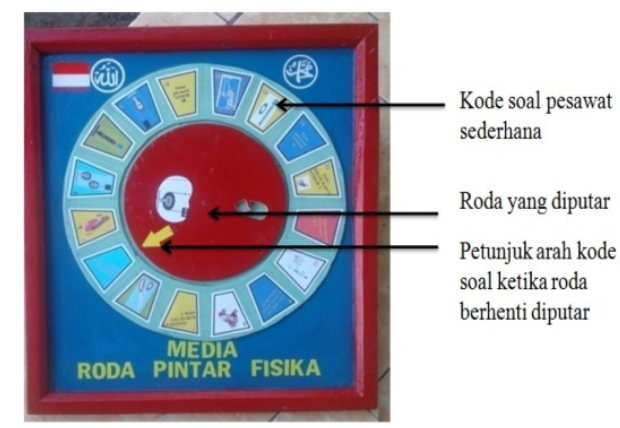

Gambar 1. Media game roda putar fisika

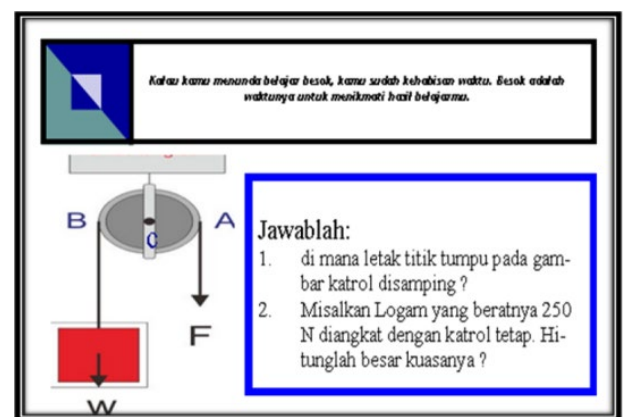

Gambar 2. Salah satu kartu soalpada roda putar

\section{Hasil validasi ahli}

Kegiatan validasi media roda putar dilakukan oleh para ahli dengan mengisi angket yang berisi 30 pernyataan yang terdiri dari kriteria pendidikan, kriteria tampilan, dan kualitas teknisMedia ini divalidasi oleh 4 ahli, 1 ahli media dan 3 ahli fisika yang menunjukan bahwa hasil untuk kriteria pendidikan 4 ahli memberikan nilai $A$, untuk kriteria tampilan 2 ahli memberikan nilai $A$ satu ahli memberikan nilai $B$ dan $C$ dan kriteria teknis 4 ahli memberikan niali $A$.

\section{Hasil uji validitas angket}

Uji validitas dilakukan pada pernyataan angket dengan menggunakan persamaan korelasi product moment. Hasil uji validitas angket motivasi belajar adalah sebagai berikut:
Tabel 4. Hasil perhitungan validitas pernyataan angket

\begin{tabular}{|c|c|c|}
\hline Jumlah pernyataan & Valid & Tidak valid \\
\hline 30 & 16 & 14 \\
\hline
\end{tabular}

Pernyataan pada angket diuji keajengan/keandalannya dengan menggunakan persamaan alpha cronbach. Hasil uji reliabelitas pada pernyataan dapat dilihat pada tabel berikut ini:

Tabel 5. Hasil perhitungan reliabelitas pernyataan angketsiswa

\begin{tabular}{|c|c|c|}
\hline Jumlah pernyataan & Reliabel & Tidak reliabel \\
\hline 30 & 16 & 14 \\
\hline
\end{tabular}

Persentase hasil perhitungan motivasi siswa tiap indikator sebelum menggunakan dan setelah menggunakan media roda putar fisika bisa di lihat pada grafik berikut ini:

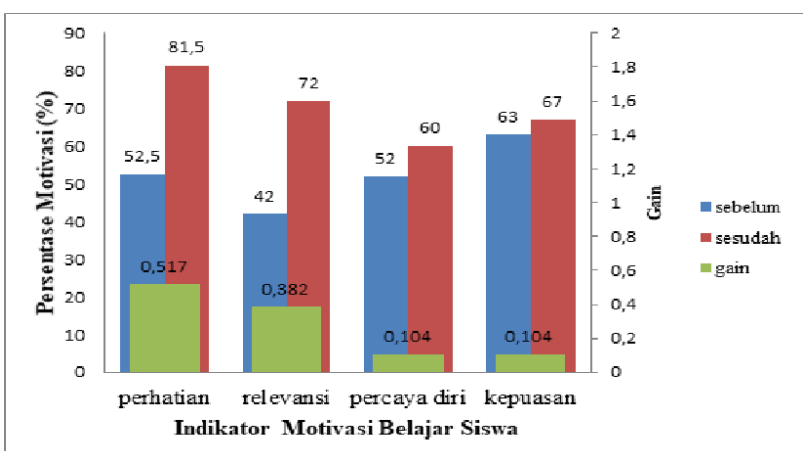

Gambar 3. Grafik persentase motivasi siswa setiap indikator sebelum dan sesudah penggunaan media roda putar fisika.

Dalam pengukuran motivasi belajar siswa digunakan teknik analisis data berupa data kuantitatif, yang diperoleh peningkatan dengan menggunakan normalisasi ( $\mathrm{N}$-gain) untuk motivasi belajar berupa indikator perhatian 0,517 dengan kriteria sedang, motivasi belajar berupa indikator kepercayaan diri 0,382 dengan kriteria sedang, motivasi belajar berupa indikator relevansi 0,102 dengan kriteria rendah, dan motivasi belajar berupa indikator kepuasan 0,061 dengan kriteria rendah Peningkatan motivasi belajar secara klasikal juga berada pada kriteria sedang dengan normalisasi gain sebesar 0,42. Dengan demikian, hasil penelitian terhadap motivasi belajar siswa mengalami peningkatan motivasi belajar siswa kelas VIII.C di MTs Al-Raisiyah Mataram, berada dalam kategori sedang. 


\section{SIMPULAN DAN SARAN Simpulan}

Berdasarkan penelitian yang telah dilaksanakan dapat disimpulkan bahwa media pembelajaran berupa media roda putar fisika dapat:

1) Teruji kevalidannya baik dari segi ahli media maupun materi, dimana untuk kriteria pendidikan 4 ahli memberikan nilai $A$, untuk kriteria tampilan 2 ahli memberikan nilai $A$, satu ahli memberika $\mathrm{B}$ dan $\mathrm{C}$ dari, serta untuk kriteria teknis 4 ahli memberikan nilai $A$.

2) Proses pembelajaran berjalan dengan lancar, karena respon siswa yang baik terhadap media roda putar fisika yang menjadi sumber belajar.

3) Media roda putar fisika dapat meningkatkan motivasi belajar siswa dari hasil pengukuran dengan menggunakan normalisasi gain ( $\mathrm{N}$-gain) dengan hasil kategori sedang. Sedangkan Peningkatan motivasi belajar secara klasikal juga berada pada kriteria sedang dengan normalisasi gain sebesar 0,42 dengan kategori sedang pada siswa kelas VIII.C MTs Al-Raisiah Mataram.

\section{SARAN}

Berdasarkan penelitiaan yang telah dilakukan, maka diberikan beberapa saran bagi peneliti selanjutnya yaitu:

1) Media roda putar fisika yang dikembangkan dapat digunakan dengan baik, namun masih memiliki kekurangan baik dari segi pendidikan, tampilan, dan kualitas teknis. Hal ini dapat dijadikan pertimbangan bagi peneliti selanjutnya untuk mengembangkan media pembelajaran yang lebih sempurna lagi.

2) Media roda putar ini dapat dikembangkan untuk semua materi Fisika untuk materi yang berbeda.

3) Penelitian ini dilaksanakan sampai pada tahap uji coba kelompok kecil. Oleh karena itu diharapkan pada penelitian selanjutnya dilaksanakan sampai pada tahap penyebaran.

\section{DAFRAR RUJUKAN}

Arikunto, S. (2009). Dasar-dasar evaluasi pendidikan. Jakarta: PT Bumi aksara

Arsyad, A. (2015). Media pembelajaran. Jakarta: PT raja grafindopersada

AzwarSaifuddin. (2014). Metode penelitian. Yogyakarta: Pustakapelajar offset

Fathiah, Alatas, dkk. (2014). Penggunaan Alat Peraga Rotation Timer Dan Roda Fleksibel Untuk Meningkatkan
Kemampuan Analisis Siswa. UIN Syarif Hidayatullah, JPPI, 1(1), 60

Mikraj, Abdul., Utami, L. S., \& Zulkarnain, Z. (2019). Pengaruh Buletin Fisika Berbentuk Buku Saku Untuk Meningkatkan Hasil Belajar Siswa Di MAN 2 Bima Kelas X Materi Hukum Newton Tahun Pelajaran 2018/2019. ORBITA:Jurnal Kajian, Inovasi dan Aplikasi Pendidikan Fisika, 5(1), 5-14

Murdaka, Bambang. Dkk. (2013). Fisika Dasar Edisi 2. Yogyakartta: C.V ANDI OFFSET

Noni istifar, R. dkk. (2015). Penerapan Pembelajaran TGT Dengan Roda Untuk Meningkatkan Aktivitas Belajar Akuntansi Siswa SMKN I Tempel.Universitas Negeri Yogyakarta, 14(1).

Nurlaelah, N., Sabaryati, J., \& Zulkarnain, Z. (2019). Pengembangan Media Pembelajaran Kotak Pop Up Untuk Meningkatkan Motivasi Belajar Siswa Materi Cahaya Dan Alat Optik Kelas VIII SMPN 19 Mataram. ORBITA:Jurnal Kajian, Inovasi dan Aplikasi Pendidikan Fisika, 5(1), 15-22

Ibrahim, I., Utami, L.S.., Darmayanti, N.W.S, (2018). Pengembangan Media Pembelajaran Game Fisika Asik (Gasik) Untuk Meningkatkan Motivasi Belajar Siswa SMP Kelas VIII Materi Pokok Cahaya Dan Sifat- Sifat Cahaya. ORBITA:Jurnal Kajian, Inovasi dan Aplikasi Pendidikan Fisika, 4(2), 6-17

Isnaini, M., Sabaryati, J., \& Fadillah, Alfiah, (2019). Pengembangan LKS G-JKO Pada Mata Pelajaran IPA Fisika Siswa MTs Al-Raisiyah Mataram. ORBITA:Jurnal Kajian, Inovasi dan Aplikasi Pendidikan Fisika, 5(1), 15-22.

Sadirman. (2016). Interaksi dan motivasi belajar mengajar. Jakarta: PT Raja Gravindo persada

Sudijono, A. (2007). Metode penelitian pendidikan. Jakarta: PT Raja Gravido Persada

Triyani, L., Islahudin, I., \& Darmayanti, N.W.S. (2019). Pengembangan Media Pembelajaran Kalseg Fisika Untuk Meningkatkan Pemahamn Konsep Siswa Kelas $X$ Materi Usaha. ORBITA:Jurnal Kajian, Inovasi dan Aplikasi Pendidikan Fisika, 5(1), 33-34,

Sudjana, Nana. (2015). Media pengajaran. Bandung: Sinar baru algesindo

Sugiyono. (2007). Metode penelitian kuantitatif, kualitatif san $R$ dan $D$. Bandung: Alfabeta 